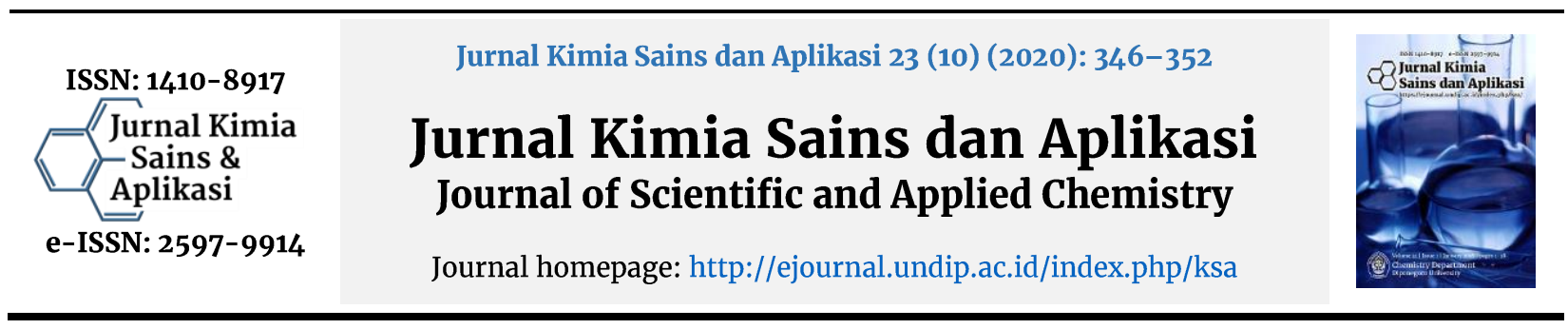

\title{
A Compatibility in the Single Cell of the NiO/LSGM/LSCF
}

\author{
Atiek Rostika Noviyanti ${ }^{a, *}$, Claudia Agesti ${ }^{a}$, Yusi Deawati ${ }^{a}$, Dani Gustaman Syarif ${ }^{b}$ \\ a Physical-Inorganic Chemistry Laboratory, Department of Chemistry, Faculty of Mathematics and Science, Universitas \\ Padjadjaran, Bandung, Indonesia \\ b Technophysics Laboratory, Applied Nuclear and Science Centre, Badan Tenaga-Nuklir Nasional (PSTNT-BATAN), \\ Bandung, Indonesia \\ * Corresponding author: atiek.noviyanti@unpad.ac.id
}

https://doi.org/10.14710/jksa.23.10.346-352

\begin{tabular}{l} 
Article Info \\
\hline Article history: \\
Received: $23^{\text {rd }}$ July 2020 \\
Revised: $21^{\text {st }}$ October 2020 \\
Accepted: $27^{\text {th }}$ October 2020 \\
Online: $31^{\text {st }}$ October 2020 \\
\hline
\end{tabular}

Keywords: ASR; SOFC; single cell; NiO/LSGM/LSCF; compatibility parameter

\begin{abstract}
The compatibility between anode, electrolyte, and cathode in a solid fuel cell determines its performance. Research on the compatibility between fuel cell components is challenging, especially for SOFCs that operate at high temperatures. Therefore, efforts to reduce the operating temperature to become intermediate temperature SOFC (IT-SOFC) are essential to facilitate compatibility between its components. $\mathrm{La}_{0.6} \mathrm{Sr}_{0.4} \mathrm{Co}_{0.2} \mathrm{Fe}_{0.8} \mathrm{O}_{3-\delta}$ (LSCF) has been recognized as one of the most promising cathode materials for (IT-SOFC) due to its high electronic conductivity and excellent electrical performance. While $\mathrm{La}_{0.8} \mathrm{Sr}_{0.2} \mathrm{Ga}_{0.8} \mathrm{Mg}_{0.2} \mathrm{O}_{3-\delta}$ (LSGM) has a high oxygen ion conductivity at low temperatures, its chemical stability is still not good. LSGM is known to have interface reactivity with other components such as NiO and LSCF in fuel cells. This study looked at the compatibility of NiO/LSGM/LSCF cells prepared by the solid chemical synthesis method. Compatibility evaluation is determined by the Thermal Expansion Coefficient (TEC) parameter using the dilatometric method, Area Specific Resistance (ASR), and TBF area morphology by Scanning Electron MicroscopeEnergy Dispersive Spectroscopy (SEM-EDS). While the conductivity of the cells is determined by Electrochemical Impedance Spectroscopy (EIS). NiO/LSGM/LSCF cells have good compatibility with a value of $78.05 \mathrm{~kg}^{-1} . \mathrm{K} . \mathrm{A} . \mathrm{s}^{3} \cdot \mathrm{\mu}^{2}$ at a temperature of $600^{\circ} \mathrm{C}$. The ASR values of cells tend to decrease with increasing temperature and conductivity values at small TEC values. Based on these parameter values, delamination in NiO/LSGM/LSCF cells did not occur.
\end{abstract}

\section{Introduction}

The increasing need for energy is a challenge in developing alternative energy sources and supporting technology. Most of today's energy needs are obtained from non-renewable energy sources, especially fossil fuels such as petroleum, coal, and natural gas [1]. Therefore an electrochemical device is needed to convert chemical energy into electrical energy with very high efficiency, which is often referred to as Solid Oxide Fuel Cell (SOFC) $[1,2]$.

SOFC is the most developed high-temperature solids fuel cell (range $600-1000^{\circ} \mathrm{C}$ ) due to its high efficiency and flexibility to hydrocarbon fuels due to its electrolytic material [3]. Its high operating temperature effectively activates the reforming process and the electrochemical oxidation of hydrocarbon fuels in the presence of a catalyst. Besides, high electrical efficiency helps reduce $\mathrm{CO}_{2}$ emissions [4]. Nevertheless, nowadays, lowering the operating temperature of SOFCs is a challenge for scientists around the world. One of them is to maintain its performance, besides economic reasons, because it can use much cheaper materials to be applied to stacks and system integration $[5,6]$.

Lower SOFC operating temperatures usually require new electrolyte materials [6] or electrolyte modifications such as doping $[7,8,9,10]$ or electrolyte composites [5, 11] to obtain electrolytes with higher conductivity. High conductivity electrolytes that have been used commercially are Yttria Stabilized Zirconia (YSZ) and 
$\mathrm{La}_{0.8} \mathrm{Sr}_{0.2} \mathrm{Ga}_{0.8} \mathrm{Mg}_{0.2} \mathrm{O}_{3-\delta}$ (LSGM). Meanwhile, cathode materials that are often chosen include lanthanum strontium cobaltite (LSCo) or lanthanum strontium cobalt ferrite (LSCF), and NiO for the anode. The selection of the right fuel cell components between electrolyte, anode, and cathode is critical to decreasing the operating temperature by reducing the electrodes' energy loss [6].

The combination of LSGM electrolyte $\left(\sigma 800^{\circ} \mathrm{C}=0.166\right.$ S.cm ${ }^{-1}$ ) [12] with LSCF cathode and NiO anode is predicted to be a fuel cell alloy capable of operating at IT-SOFC operating temperatures $\left(600-800^{\circ} \mathrm{C}\right)[13,14]$. LSCF has a high level of electronic conductivity and has an electrical performance as a cathode material [15]. Meanwhile, Ni/YSZ anode has been widely used as a SOFC anode because of its high electrochemical activity against $\mathrm{H}_{2}$ oxidation as well as high stability at high operating temperatures $[6,16]$. Therefore, this study made NiO/LSGM/LSCF single cells to test their compatibility. The performance of similar cells, such as Ni-Sc/LSGM/LSCF-Ag and YSZ/Ni-LSGM-LSCF, has been previously reported $[6,17]$, which was measured at a temperature of $600^{\circ} \mathrm{C}$. In this study, the cell performance was measured at lower temperatures, i.e., from $300-600^{\circ} \mathrm{C}$, to determine its electrochemical character at lower temperatures.

\section{Methodology}

\subsection{Materials and Tools}

The tools used in this research are mortar, analytical balance, ball mill agate, furnace, oven, pellet maker, and glassware. Electrolyte, anode, and cathode morphology was determined by SEM-EDS (SEM: JEOL JSM-6360LA, SEM-EDS: Hitachi-EDAX Team), while structural measurements were used XRD (Rigaku: MiniFlex600) to determine the ASR value and total conductivity, used Impedance spectroscopy (LCR meter GW Instek 8105G), TEC values were used with a micrometer screw.

The materials used in this study include LSGM ( $99 \%$ trace rare earth metal basic) as an electrolyte, silver paste, NiO (99.999\% trace metals basic) as an anode, LSCF (6428 Sigma-Aldrich) as a cathode, DMF, and cellulose acetate as a binder. The material used was previously characterized by its structure with XRD (Rigaku: MiniFlex600).

\subsection{Preparation of NiO, LSGM, and LSCF Pellet}

NiO, LSGM, and LSCF pellets were made with a diameter of $0.798 \pm 1.045 \mathrm{~cm}$, a cross-sectional area of $5.003 \pm 8.58 \mathrm{~cm}^{2}$, and a thickness of $0.2425 \pm 0.353 \mathrm{~cm}$. Each pellet was compacted under a pressure of 6000 kg. $\mathrm{cm}^{2}$.

\subsection{Determination of the Thermal Expansion Coefficient (TEC) of NiO/LSGM/LSCF}

The TEC of the NiO, LSGM, and LSCF fuel cell components were determined by dilatometric techniques using micrometer couplers. Each compacted NiO, LSGM, and LSCF pellet was then heated in a specially designed furnace to $1100^{\circ} \mathrm{C}$, and each increase in temperature of $100^{\circ} \mathrm{C}$ was re-measured its expansion to determine the TEC value [18].

\subsection{Fabrication of NiO/LSGM/LSCF Cell.}

NiO/LSGM/LSCF cells were prepared by combining the three components, such as a sandwich consisting of anode/electrolyte/cathode, through gradual sintering, which was initiated by combining LSGM with NiO, followed by merging with LSCF. One side of the LSGM was coated with NiO anode slurry and then sintered at $900^{\circ} \mathrm{C}$ for 5 hours. After cooling, the other side was coated with an LSCF cathode and then sintered at $800^{\circ} \mathrm{C}$ for 2 hours. This sintering process can also simultaneously remove cellulose acetate binders dissolved in DMF. The two sides of the NiO/LSGM/LSCF cells were then coated with silver paste $(\mathrm{Ag})$ as a current collector at each electrode. The cells were sintered again to $600^{\circ} \mathrm{C}$ [6] and then tested their electrochemical performance using EIS (LCR meter GW Instek 8105G).

The morphology between anode-electrolyte and electrolyte-cathode was observed by SEM-EDS (EDS (SEM: JEOL JSM-636OLA, SEM-EDS: Hitachi-EDAX Team) to ascertain the level of chemical reactivity that may occur.

\subsection{Area Specific Resistance (ASR)}

ASR is determined by impedance spectroscopy technique (LCR meter GW Instek $8105 \mathrm{G}$ ) at a frequency of $20-5000 \mathrm{~Hz}$ with a temperature range of $300-600^{\circ} \mathrm{C}$, signal AC $=1.00 \mathrm{~V}$. The ASR value is calculated from the total measured resistance.

\subsection{Total Conductivity}

The total conductivity is determined from the total resistance value $\left(R_{t o t}\right)$ measured by the EIS. This total resistance consists of electrolyte ohmic resistance $\left(R_{s}\right)$, electrode ohmic polarization resistance $\left(R_{o}\right)$, charge transfer resistance $\left(R_{c t}\right)$, and electrode diffusion resistance (Rdif). This total conductivity is calculated using the following equation:

$$
\sigma=\mathrm{L} /(\mathrm{R} . \mathrm{A})
$$

where: $\sigma=$ conductivity $/ \mathrm{Scm}^{-1}$

$$
\begin{aligned}
& L=\text { pellet thickness } / \mathrm{cm} \\
& R=\text { Resistance } \Omega \\
& A=\text { electrolyte area effective } / \mathrm{cm}^{2}
\end{aligned}
$$

\section{Results and Discussion}

The determination of the compatibility of NiO, LSGM, and LSCF was completed by the analysis of the structure and surface and cross-section morphology of each cell component, then analysis of TEC and ASR.

\subsection{Characterization of Structure and Morphology of NiO/LSGM/LSCF}

X-ray diffraction patterns of NiO, LSGM, and LSCF are shown in Figure 1. 


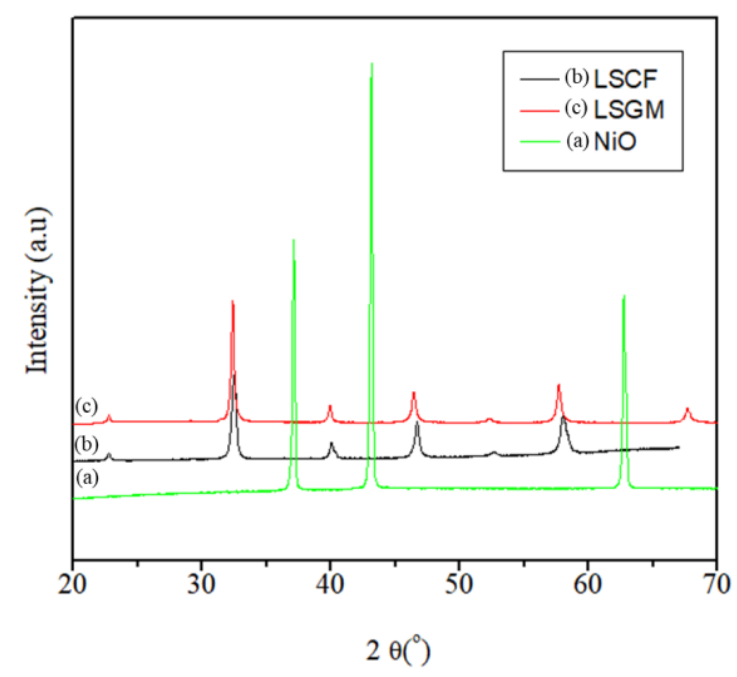

Figure 1. X-ray diffraction pattern of (a) NiO, (b), LSCF (c) LSGM.

LSGM single phase which refers to ICSD standard No. 98-009-8170 has a cubic crystal form with a space group Pm-3m $(a=b=3.92(2) ; c=3.92(2))$, where the typical peak is located at $2 \theta=32.34^{\circ}\left(\begin{array}{lll}0 & 1 & 1\end{array}\right)$. While the typical peak of $\mathrm{NiO}$ is at $2 \theta=43.09^{\circ}\left(\begin{array}{lll}0 & 0 & 2\end{array}\right)$, which adopts (1)). Likewise, LSCF shows a typical peak at $2 \theta=32.44(0$ 11) refers to ICSD 98-015-8799, with a cubic structure with space group Pm-3m ( $a=b=3.88$ (2); $c=3.88$ (2) $\AA$ ).

The possible chemical reactivity between NiO/LSGM and LSCF/LSGM was observed with changes in surface morphology and the cross-section of the respective grain boundaries (Figure 2).

The difference in layers between the NiO and LSCF anode and the LSGM electrolyte is visible. The LSGM electrolyte has a relatively denser morphology than the hollow anode and cathode regions. The possible chemical reactivity in this area indicates a fusion of the electrolyte-anode boundary, which means that the electrodes are likely to have diffused into the electrolyte, which allows a deficiency in electrochemical performance. In the study, it could be concluded that there was no significant reactivity for both NiO/LSGM and alsoLSGM/LSCF [19].

The anode pores are useful for passing hydrogen, which then diffuses into the Triple Phase Boundary (TPB). The unsuitable cavity size can result in $\mathrm{H}_{2} \mathrm{O}$ molecules trapped in the cavity. If $\mathrm{H}_{2} \mathrm{O}$ evaporation is slower than formation, the $\mathrm{H}_{2} \mathrm{O}$ molecule affects SOFC cell compatibility, namely in the form of SOFC resistance. To ensure reactivity in the border area, an analysis of the area elements was carried out (Figure 2). Meanwhile, the cavity in the cathode functions so that oxygen gas can diffuse through the cavity. The probability of meeting electrons, oxygen gas, and electrolytes on the TPB can increase. On the other hand, electrolytes must have low porosity and be relatively dense to prevent the diffusion of oxygen gas into the bulk phase of the electrolyte, which can interfere with the electrochemical reaction process [20, 21].

In addition to the morphological observations between the electrodes on the cell components, the chemical reactivity of these cells was also confirmed by the composition of the elements at the boundary area of the components tested by EDS (Figure 3). Based on Figure 3, the previous conclusion that there is no chemical activity between the anode and cathode with electrolytes is strengthened by the absence of other elements besides the constituents of NiO, LSCF, and LSGM (Table 1 and Table 2).

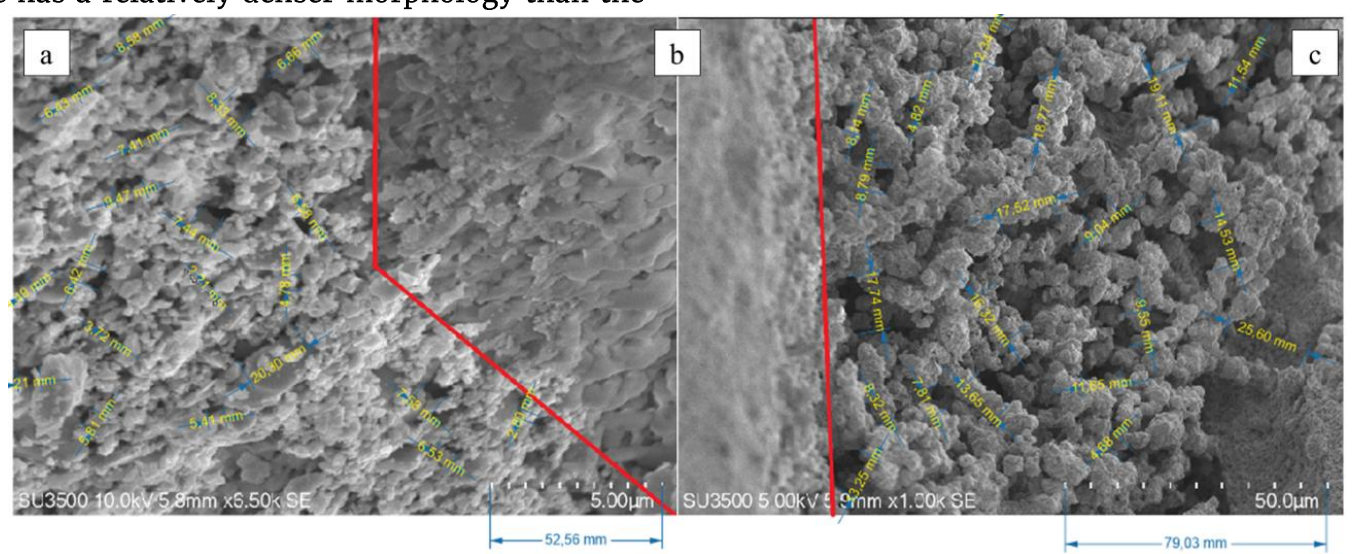

Figure 2. Cross-sectional SEM micrographs of sintered LSGM/LSCF and LSGM/NiO (a) LSCF and (b) LSGM and (c) $\mathrm{NiO}$.
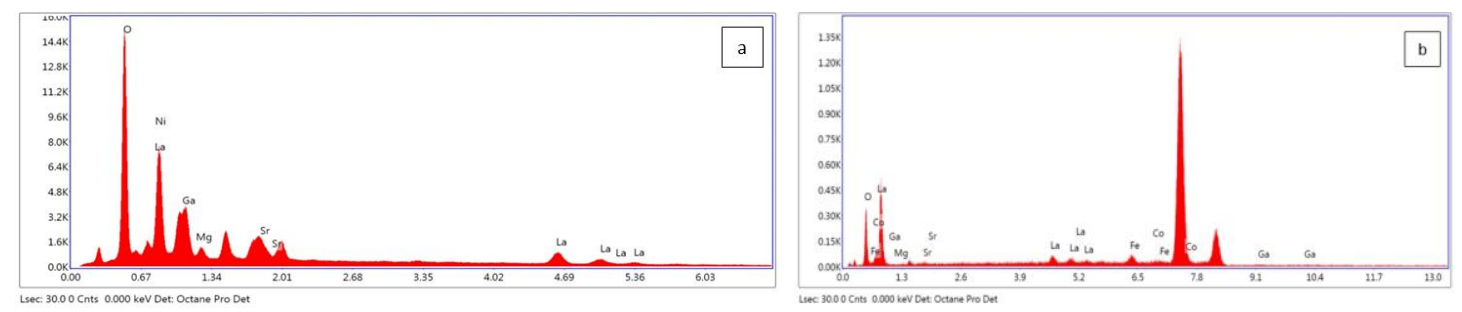

Figure 3. EDS spectrum of selected area on the LSGM electrolyte layer in the cross section of (a) electrolyte / anode: LSGM-NiO, (b) electrolyte / cathode: LSGM-LSCF. 
Table 1. Percentage of elements in the LSGM selection area near the $\mathrm{NiO}$ anode area.

\begin{tabular}{ccc}
\hline Element & \% Mass & Composition of element (\%) \\
\hline $\mathrm{La}$ & 29.72 & 8.62 \\
$\mathrm{Sr}$ & 10.36 & 4.77 \\
$\mathrm{Ga}$ & 17.27 & 9.98 \\
$\mathrm{Mg}$ & 1.42 & 2.36 \\
$\mathrm{O}$ & 25.08 & 63.19 \\
$\mathrm{Ni}$ & 16.13 & 11.08 \\
\hline
\end{tabular}

Table 2. Percentage of elements in the LSGM selection area near the LSCF cathode area.

\begin{tabular}{ccc}
\hline Element & \% Mass & Composition of element (\%) \\
\hline $\mathrm{La}$ & 18.03 & 4.31 \\
$\mathrm{Sr}$ & 1.4 & 0.53 \\
$\mathrm{Ga}$ & 3.92 & 1.87 \\
$\mathrm{Mg}$ & 0.50 & 0.68 \\
$\mathrm{O}$ & 32.44 & 67.26 \\
$\mathrm{Co}$ & 19.37 & 10.91 \\
$\mathrm{Fe}$ & 24.34 & 14.46 \\
\hline
\end{tabular}

\subsection{Thermal Expansion Coefficient (TEC)}

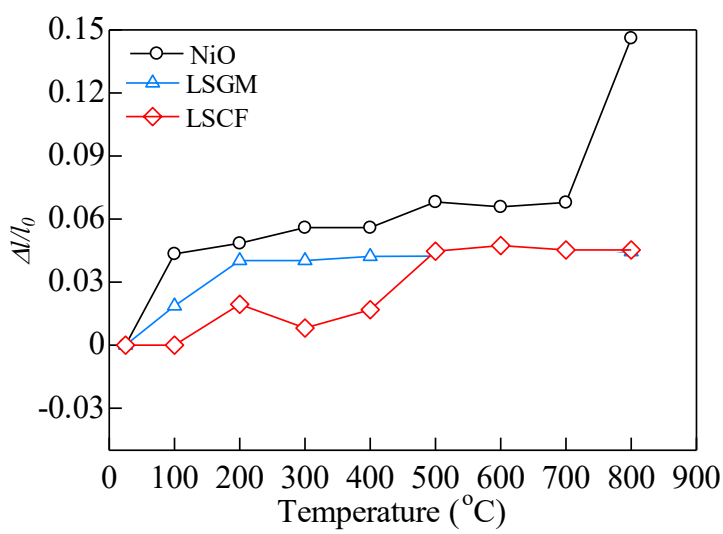

Figure 4. Effect of temperature on changes in the TEC value of LSCF, LSGM, and NiO.

In this study, TEC measurements were carried out at a temperature of $25-800^{\circ} \mathrm{C}[22,23]$. The increase in sample dimensions (diameter and height of pellets) is measured using a screw micrometer. The length of LSCF,
LSGM, and NiO increases with increasing temperature. $\mathrm{NiO}$ tends to have a relatively faster and higher dilatation ratio, especially at $1100^{\circ} \mathrm{C}$ compared to LSGM and LSCF (Figure 4).

The TEC NiO pattern is relatively different compared to LSCF and LSGM, which tend to continue to rise at a temperature of $800^{\circ} \mathrm{C}$, meaning that the maximum value has not been reached. A high increase in the TEC value can significantly increase the coefficient of expansion. This can affect other parameter values, which also affect cell compatibility. The comparison of TEC values from NiO, LSCF, and LSGM in literature and research results is presented in Table 3.

Table 3. Comparison of TEC values on several SOFC components.

\begin{tabular}{cccc}
\hline $\begin{array}{c}\text { Cell } \\
\text { components }\end{array}$ & Literature & $\begin{array}{c}\text { Theories } \\
\text { value }\end{array}$ & $\begin{array}{c}\text { This } \\
\text { research }\end{array}$ \\
\hline LSGM & Tao et al. [24] & 11.5 & 11.23 \\
NiO & Madelung et al. [25] & 13.9 & 17.53 \\
LSCF & Corbel et al. [26] & 16.30 & 5.61 \\
\hline
\end{tabular}

One of the eligibility requirements of a SOFC cell is that the TEC value of the electrode material must be slightly higher than that of the electrolyte. However, a mismatch that is too large can cause the electrolyte to break down easily, and this can change the structure of the SOFC cell as the operating temperature rises. In this study, quite a large difference in TEC was found at the LSCF cathode. The cause of the decrease in TEC value from LSCF in this study cannot be explained; however, cell damage at the time of fabrication was not found. The difference in the TEC value, which is very large between the results of this study and the references that have been reported, can be caused by several things, including differences in the morphology of LSCF due to differences in the synthesis method used.

\subsection{ASR Value and Cell Conductivity}

EIS testing was carried out in a temperature range of $300-600^{\circ} \mathrm{C}$ using an LCR meter at a frequency of $20-$ $5000 \mathrm{~Hz}$. Data displayed is data in the form of real $\mathrm{Z}\left(\mathrm{Z}^{\prime}\right)$ and imaginary Z (Z") of NiO/LSGM/LSCF cells (Table 4).

Table 4. Real Z (Z') and imaginary Z (Z") values of NiO/LSGM/LSCF cells

\begin{tabular}{|c|c|c|c|c|c|c|c|c|}
\hline \multirow{2}{*}{ Frequency(Hz) } & \multicolumn{2}{|c|}{$300^{\circ} \mathrm{C}$} & \multicolumn{2}{|c|}{$400^{\circ} \mathrm{C}$} & \multicolumn{2}{|c|}{$500^{\circ} \mathrm{C}$} & \multicolumn{2}{|c|}{$600^{\circ} \mathrm{C}$} \\
\hline & $\mathrm{Z}^{\prime} \Omega \cdot \mathrm{cm}^{-1}$ & $\mathrm{Z}^{\prime \prime} \Omega \cdot \mathrm{cm}^{-1}$ & $\mathrm{Z}^{\prime} \Omega . \mathrm{cm}^{-1}$ & $\mathrm{Z}^{\prime \prime} \Omega \cdot \mathrm{cm}^{-1}$ & ${ }^{1} \mathrm{Z}^{\prime} \Omega \cdot \mathrm{cm}^{-1}$ & $\mathrm{Z}^{\prime \prime} \Omega . \mathrm{cm}^{-1}$ & $\mathrm{Z}^{\prime} \Omega \cdot \mathrm{cm}^{-1}$ & $\mathrm{Z}^{\prime \prime} \Omega \cdot \mathrm{cm}^{-1}$ \\
\hline 300 & -65.78 & 1.39 & -65.72 & 1.45 & -66.09 & 1.55 & -65.87 & 1.53 \\
\hline 500 & -62.99 & 2.31 & -63.83 & 2.98 & -63.47 & 2.62 & -63.90 & 2.57 \\
\hline 700 & -60.81 & 3.59 & -61.06 & 3.71 & -61.15 & 3.59 & -61.42 & 3.72 \\
\hline 1000 & -57.24 & 5.11 & -57.47 & 5.06 & -57.54 & 5.17 & -57.79 & 5.11 \\
\hline 1500 & -56.66 & 7.61 & -56.91 & 7.66 & -57.09 & 7.66 & -57.10 & 7.67 \\
\hline 2000 & -56.02 & 10.12 & -56.24 & 10.19 & -56.31 & 10.18 & -56.48 & 10.23 \\
\hline 2500 & -55.44 & 12.58 & -55.66 & 12.66 & -55.76 & 12.60 & -55.84 & 12.62 \\
\hline 3000 & -54.79 & 15.06 & -55.00 & 14.98 & -54.98 & 15.05 & -55.19 & 15.09 \\
\hline 3500 & -54.29 & 17.55 & -54.32 & 17.53 & -54.61 & 17.55 & -54.79 & 17.52 \\
\hline 4000 & -54.21 & 20.06 & -54.29 & 20.07 & -54.52 & 20.04 & -54.68 & 19.97 \\
\hline 4500 & -54.18 & 22.58 & -54.26 & 22.57 & -54.49 & 22.48 & -54.58 & 22.46 \\
\hline 5000 & -54.09 & 25.07 & -54.07 & 25.05 & -54.45 & 25.00 & -54.45 & 25.01 \\
\hline
\end{tabular}


The NiO/LSCF/LSGM SOFC cells' compatibility is shown in the Nyquist diagram (Figure 5). The Nyquist diagram is generally a semicircular curve, both in response to grain phase resistance and phases between grains, but it is more like a quarter circle in this study. This difference can occur due to different types of electrochemistry in the cell.

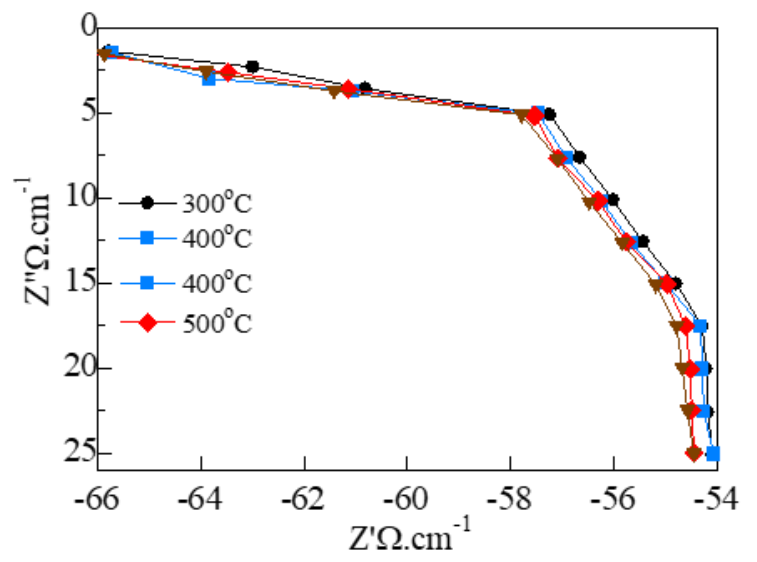

Figure 5. Nyquist diagram for SOFC NiO/LSGM/LSCF cells.

It is necessary to quantify the Nisquist profile to map the measured polarization resistance and ohmic resistance values in NiO/LSGM/LSCF cells. Based on the resulting Nisquist profile, it is difficult to separate the resistance resulting from the grain phase and grain boundaries, as well as the polarization at the electrodes in NiO/LSGM/LSCF cells. The resulting Nyquist diagram has a dominant form of loop inductance, where the reactance is inductive. Inductive is a type of resistance that resists changes in direction in an AC circuit. When $\mathrm{AC}$ passes through a component containing a reactance, energy can be stored and released in the form of a magnetic field. In this case, the reactance is inductive, as mentioned in the previous literature [27].

Table 5. ASR values for single-cell NiO/LSGM/LSCF.

\begin{tabular}{ccccc}
\hline Temp $/{ }^{\circ} \mathrm{C}$ & $\mathrm{Rs} / \Omega$ & $\mathrm{R} 1 / \Omega$ & $\mathrm{L} / \mathrm{H}$ & $\mathrm{ASR} / \Omega . \mathrm{cm}^{2}$ \\
\hline 300 & 24.79 & $1 \times 1020$ & $6.5716 \times 10^{-4}$ & 1.3582 \\
400 & 21.82 & $1 \times 1020$ & $6.4104 \times 10^{-4}$ & 1.1869 \\
500 & 20 & $1 \times 1020$ & $6.1231 \times 10^{-4}$ & 0.9777 \\
600 & 19 & $1 \times 1020$ & $5.9673 \times 10^{-4}$ & 0.9266 \\
\hline
\end{tabular}

The decrease in the ASR value occurs with the increase in temperature. In the SOFC principle, the higher the temperature, the smaller the resistance or ASR. From the results of calculations in this study, it can be seen that the inductance $(\mathrm{L})$ value also decreases with the increase in temperature. This temperature increase also affects the increase in the electrons' conductivity in the grain and grain boundaries of the anode as the temperature increases and the resistance decreases. The ASR value, which decreases with increasing temperature, indicates that the resulting cells are compatible. The decrease in the ASR value and the increase in temperature can occur because the resistance and reactance values in SOFC cells have decreased, which affects ASR. These results are confirmed by the results of the calculations in Table 5.

\subsection{Total conductivity of NiO/LSGM/LSCF cell}

The total conductivity value is calculated from the total resistance measured $R_{\text {total }}\left(\mathrm{R}_{s}+\mathrm{R}_{1}+\mathrm{W}\right)$. A pellet with a thickness of (1) $0.15 \mathrm{~cm}$ and a cross-sectional area of pellets (A) $0.7857 \mathrm{~cm}^{2}$, the total conductivity values for NiO/LSGM/LSCF cells are summarized in Table 6.

Table 6. Total conductivity of NiO/LSGM/LSCF cell.

\begin{tabular}{ccc}
\hline $\begin{array}{c}\text { Temp } \\
\left({ }^{\circ} \mathrm{C}\right)\end{array}$ & $\begin{array}{c}R_{\text {total }} \\
\left(R_{s}+R_{1}+W\right)\end{array}$ & $\begin{array}{c}\text { Total conductivity/ } \\
\text { S.cm }\end{array}$ \\
\hline 600 & 19.4 & $9.9 \times 10^{-3}$ \\
500 & 20.5 & $9.3 \times 10^{-3}$ \\
400 & 22.7 & $8.4 \times 10^{-3}$ \\
300 & 26.1 & $7.3 \times 10^{-3}$ \\
\hline
\end{tabular}

The higher the operating temperature, the higher the cell conductivity (Figure 6). This means that up to a temperature of $600^{\circ} \mathrm{C}$, compatibility between components is maintained.

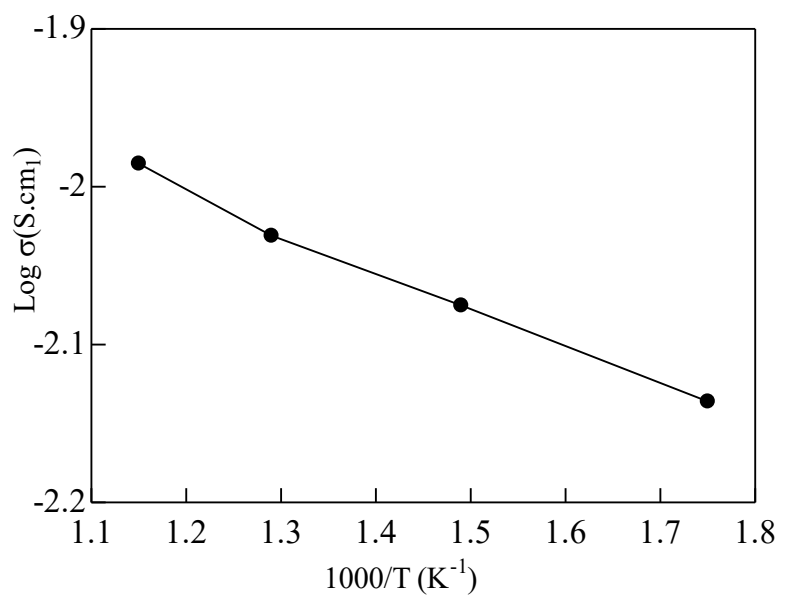

Figure 6. The conductivity of the NiO/LSGM /LSCF cell.

The total conductivity of NiO/LSGM/LSCF cells (Figure 6) is the sum of all electrical conductivity involved in the cell-derived from the ionic conductivity of the LSGM electrolyte and the electronic conductivity of the NiO anode and the LSCF cathode. The conductivity derived from the LSGM in this cell was $0.0093{\mathrm{~S} . \mathrm{cm}^{-1}}^{-1}$ $500^{\circ} \mathrm{C}$, which contributed significantly to the increase in the total conductivity value of the cell.

\subsection{Compatibility of NiO/LSGM/LSCF Cell}

Compatibility parameters of NiO/LSGM/LSCF cells are shown in Table 7.

Table 7. Compatibility parameter of NiO/LSGM/LSCF Cell.

\begin{tabular}{ll}
\hline Parameter $\left(600^{\circ} \mathrm{C}\right)$ & Value \\
\hline$\Delta \mathrm{TEC}$ & \\
Anode/electrolyte $\left(300-600^{\circ} \mathrm{C}\right)$ & $17.53-11.23=6.3$ \\
cathode/electrolyte $\left(300-600^{\circ} \mathrm{C}\right)$ & $11.23-5.61=5.6$ \\
Reactivity $/ \%$ & $(\mathrm{Ni}=11.08 \%, \mathrm{Co}=10.91 \%$, \\
& $\mathrm{Fe}=14.46 \%)$ \\
$\mathrm{ASR}_{\text {total cell }} / \Omega . \mathrm{cm}^{2}$ & 0.9266 \\
${\text { Total conductivity } / \mathrm{S} . \mathrm{cm}^{-1}}$ & 0.0093 \\
\hline
\end{tabular}


Based on the compatibility parameter values in Table 6, the single cell SOFC NiO/ LSGM/LSCF operated at $600{ }^{\circ} \mathrm{C}$ has a compatibility value of $78.05 \mathrm{~kg}^{-1} \cdot \mathrm{K} . A \cdot \mathrm{s}^{3} \cdot \mu^{2}$ which is calculated using the following compatibility equation:

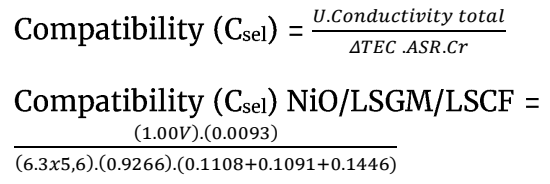

Compatibility value of NiO/LSGM/LSCF cell is in the quartile range $\mathrm{Q3}^{-} \mathrm{Q} 4$ (Table 8).

Table 8. Quartile ranges of SOFC cell compatibility levels

\begin{tabular}{ccc}
\hline Quartile & $\begin{array}{c}\text { Compatibility Value } \\
\left(\mathrm{kg}^{-1} \cdot \mathrm{K} \cdot \mathrm{A} \cdot \mathrm{s}^{3} \cdot \mathrm{\mu}^{2}\right)\end{array}$ & Compatibility Level \\
\hline $\mathrm{Q}_{0}-\mathrm{Q}_{1}$ & $1.63 \times 10^{-8}-1.72 \times 10^{-5}$ & not compatible \\
$\mathrm{Q}_{1}-\mathrm{Q}_{2}$ & $1.72 \times 10^{-5}-8.45 \times 10^{-4}$ & slightly Compatible \\
$\mathrm{Q}_{2}-\mathrm{Q}_{3}$ & $8.45 \times 10^{-4}-13.63$ & Enough Compatible \\
$\mathrm{Q}_{3}-\mathrm{Q}_{4}$ & $13.63-30,000$ & Compatible \\
\hline
\end{tabular}

Thus, NiO/LSGM/LSCF cells have an adequate cell compatibility level, both thermal and reactivity levels. The low reactivity between the electrolyte and the electrodes does not significantly affect the cell's electrochemical activity. This fact is supported by the relatively small ASR value of the cell $0.9266 \Omega . \mathrm{cm}^{2}$, the relatively high total conductivity $\left(0.0093{\left.\mathrm{~S} . \mathrm{cm}^{-1}\right)}^{2}\right.$ at an operating temperature of $600^{\circ} \mathrm{C}$.

\section{Conclusion}

Single-cell SOFC of NiO/LSGM/LSCF have been successfully fabricated with the compatibility value is $78.05 \mathrm{~kg}^{-1} \cdot \mathrm{K} . A \cdot \mathrm{s}^{3} \cdot \mu^{2}$. This value indicates that the compatibility between NiO, LSGM, and LSCF is good, within the range of $\mathrm{Q}_{3}-\mathrm{Q}_{4} \quad(13.63-30,000$ The electrochemical properties of cells in the temperature range $300-600^{\circ} \mathrm{C}$ indicate loop inductance, a type of resistance that resists directional changes in an $\mathrm{AC}$ circuit.

\section{Acknowledgments}

We would like to express our gratitude to the Ministry of Research and Technology / National Research and Innovation Agency, through the Grants "Excellent Basic Research on Higher Education" (PDUPT) No. 1827/UN6.3.1/LT/2020 for their funding support.

\section{References}

[1] Pengfei Zhu, Jing Yao, Chenhui Qian, Fusheng Yang, Ekambaram Porpatham, Zaoxiao Zhang, Zhen Wu, High-efficiency conversion of natural gas fuel to power by an integrated system of SOFC, HCCI engine, and waste heat recovery: Thermodynamic and thermo-economic analyses, Fuel, 275, (2020), 117883 https://doi.org/10.1016/j.fuel.2020.117883

[2] David M. Bastidas, Shanwen Tao, John T. S. Irvine, A symmetrical solid oxide fuel cell demonstrating redox stable perovskite electrodes, Journal of Materials Chemistry, 16, 17, (2006), 1603-1605 http://dx.doi.org/10.1039/B600532B

[3] F. Ramadhani, M. A. Hussain, H. Mokhlis, S. Hajimolana, Optimization strategies for Solid Oxide Fuel Cell (SOFC) application: A literature survey, Renewable and Sustainable Energy Reviews, 76, (2017), 460-484 https://doi.org/10.1016/j.rser.2017.03.052

[4] Kevin Huang, John B. Goodenough, Solid Oxide Fuel Cell Technology: Principles, Performance and Operations, Elsevier Science, Cambridge, 2009,

[5] Atiek Rostika Noviyanti, Ferli S. Irwansyah, Sahrul Hidayat, Arie Hardian, Dani Gustaman Syarif, Yati B. Yuliyati, Iwan Hastiawan, Preparation and conductivity of composite apatite $\mathrm{La}_{9.33} \mathrm{Si}_{6} \mathrm{O}_{26}$ (LSO)$\mathrm{Zr}_{0.85} \mathrm{Y}_{0.15} \mathrm{O}_{1.925}$ (YSZ), AIP Conference Proceedings, 1712, 1, (2016), 050002 https://doi.org/10.1063/1.4941885

[6] Changsing Hwang, Chun-Huang Tsai, Chih-Hung Lo, Cha-Hong Sun, Plasma sprayed metal supported YSZ/Ni-LSGM-LSCF ITSOFC with nanostructured anode, Journal of Power Sources, 180, 1, (2008), 132142 https://doi.org/10.1016/j.jpowsour.2008.01.075

[7] Atiek Rostika Noviyanti, Diana Rakhmawaty Eddy, Annisa Anshari, Synthesis of the Bi-doped Apatitetype Phases $\mathrm{La}_{10-\mathrm{x}} \mathrm{Bi}_{\mathrm{x}} \mathrm{Si}_{6} \mathrm{O}_{27}(\mathrm{x}=0.5$, and 1$)$ by Hydrothermal Method, Procedia Chemistry, 17, (2015), 16-20 https://doi.org/10.1016/j.proche.2015.12.111

[8] Atiek Rostika Noviyanti, Bambang Prijamboedi, I. Nyoman Marsih, Rino R. Mukti, Ismunandar, Conductivity and solid state 29Si NMR studies of apatite-type lanthanum silicate prepared by hydrothermal method, $2^{\text {nd }}$ International Conference on Instrumentation, Communications, Information Technology, and Biomedical Engineering, Bandung, Indonesia, 2011

https://doi.org/10.1109/ICICI-BME.2011.6108653

[9] Atiek Rostika Noviyanti, Nur Akbar, Iwan Hastiawan, Iman Rahayu, Yoga Trianzar Malik, Bi Doping Effect on the Conductivity of Lanthanum Silicate Apatite, Materials Science Forum, 2019 https://doi.org/10.4028/www.scientific.net/MSF.966.451

[10] A. R. Noviyanti, D. R. Eddy, F. Lastiyanti, I. Rahayu, D. G. Syarif, T. Saragi, Risdiana, Synthesis and conductivities of the Ti-doped apatite-type phases $\mathrm{La}_{9.33} \mathrm{Si}_{6-\mathrm{x}} \mathrm{Ti}_{\mathrm{x}} \mathrm{O}_{26}$, Journal of Physics: Conference Series, 1080, (2018), 012018 http://dx.doi.org/10.1088/1742-6596/1080/1/012018

[11] Atiek Rostika Noviyanti, Iwan Hastiawan, Yati B. Yuliyati, Iman Rahayu, Desy Rosyani, Dani Gustaman Syarif, LSO apatite-YSZ composite as a solid electrolyte for solid oxide fuel cells, AIP Conference Proceedings, 1848, 1, (2017), 040001 https://doi.org/10.1063/1.4983939

[12] Yoga Trianzar Malik, Atiek Rostika Noviyanti, Putri Rizka Lestari, Thermomechanical Analysis of Various Solid-oxide-fuel-cell Components Using Simple Analog Micrometer Measurements, Makara Journal of Science, 24, 1, (2020), 17-23 https://doi.org/10.7454/mss.v24i1.11725

[13] Alexander Sobolev, Paz Stein, Konstantin Borodianskiy, Synthesis and characterization of $\mathrm{NiO}$ colloidal ink solution for printing components of solid oxide fuel cells anodes, Ceramics International, 
46, 16, Part A, (2020), 25260-25265 https://doi.org/10.1016/j.ceramint.2020.06.318

[14]Jie Zhu, Guolin Cao, Yunjiao Li, Xiaoming Xi, Zhuomin Jin, Bin Xu, Wei Li, Efficient utilisation of rod-like nickel oxalate in lithium-ion batteries: A case of $\mathrm{NiO}$ for the anode and $\mathrm{LiNiO}_{2}$ for the cathode, Scripta Materialia, 178, (2020), 51-56

https://doi.org/10.1016/j.scriptamat.2019.10.051

[15] Baoan Fan, Jiabao Yan, Xiaochao Yan, The ionic conductivity, thermal expansion behavior, and chemical compatibility of $\mathrm{La}_{0.54} \mathrm{Sr}_{0.44} \mathrm{Co}_{0.2} \mathrm{Fe}_{0.8} \mathrm{O}_{3-\delta}$ as SOFC cathode material, Solid State Sciences, 13, 10, (2011), 1835-1839

https://doi.org/10.1016/j.solidstatesciences.2011.07.007

[16] H. A. Taroco, J. A. F. Santos, R. Z. Domingues, T. Matencio, Ceramic materials for solid oxide fuel cells, in: Advances in ceramics-Synthesis and Characterization, processing and specific applications, 2011, https://doi.org/10.5772/18297

[17] Yoichi Endo, Kazuya Sasaki, Akihiro Suzuki, Takayuki Terai, Performance of anode microstructure controlled Ni-ScSZ/LSGM/LSCF-Ag SOFCs by low temperature fabrication process, ECS Transactions, 35, 1, (2011), 615 https://doi.org/10.1149/1.3570040

[18] Ludger Blum, An Analysis of Contact Problems in Solid Oxide Fuel Cell Stacks Arising from Differences in Thermal Expansion Coefficients, Electrochimica Acta, 223, (2017), 100-108 https://doi.org/10.1016/j.electacta.2016.12.016

[19]Fangjun Jin, Jincheng Liu, Yu Shen, Tianmin He, Improved electrochemical performance and thermal expansion compatibility of $\mathrm{LnBaCoFeO}_{5+\delta}-$ $\mathrm{Sm}_{0.2} \mathrm{Ce}_{0.8} \mathrm{O}_{1.9}$ ( $\mathrm{LnPr}$ and $\mathrm{Nd}$ ) composite cathodes for IT-SOFCs, Journal of Alloys and Compounds, 685, (2016), 483-491

https://doi.org/10.1016/j.jallcom.2016.05.322

[20]Michał Mosiałek, Aneta Michna, Małgorzata Dziubaniuk, Elżbieta Bielańska, Algimantas Kežionis, Tomas Šalkus, Edvardas Kazakevičius, Barbara Bożek, Aneta Krawczyk, Jan Wyrwa, Antanas Feliksas Orliukas, Composite cathode material LSCF-Ag for solid oxide fuel cells obtained in one step sintering procedure, Electrochimica Acta, 282, (2018), 427-436

https://doi.org/10.1016/j.electacta.2018.06.063

[21] Francisco J. A. Loureiro, Daniel A. Macedo, Rubens M. Nascimento, Moisés R. Cesário, João P. F. Grilo, Aleksey A. Yaremchenko, Duncan P. Fagg, Cathodic polarisation of composite LSCF-SDC IT-SOFC electrode synthesised by one-step microwave selfassisted combustion, Journal of the European Ceramic Society, 39, 5, (2019), 1846-1853

https://doi.org/10.1016/j.jeurceramsoc.2019.01.013

[22]Yoga Trianzar Malik, Atiek Rostika Noviyanti, Dani Gustaman Syarif, Lowered Sintering Temperature on Synthesis of $\mathrm{La}_{9.33} \mathrm{Si}_{6} \mathrm{O}_{26}$ (LSO) $\mathrm{La}_{0.8} \mathrm{Sr}_{0.2} \mathrm{Ga}_{0.8} \mathrm{Mg}_{0.2} \mathrm{O}_{2.55} \quad$ (LSGM) Electrolyte Composite and the Electrical Performance on $\mathrm{La}_{0.7} \mathrm{Ca}_{0.3} \mathrm{MnO}_{3}$ (LCM) Cathode, Jurnal Kimia Sains dan Aplikasi, 21, 4, (2018), 205-210 https://doi.org/10.14710/jksa.21.4.205-210

[23]Yoga Trianzar Malik, Atiek Rostika Noviyanti, Nur Akbar, Iwan Hastiawan, Togar Saragi, Structure, chemical stability and magnetic properties of lanthanum silicate oxide apatite synthesized by hydrothermal method, Materials Science Forum, 2019 https://doi.org/10.4028/www.scientific.net/MSF.966.415

[24]S. W. Tao, J. T. S. Irvine, J. A. Kilner, An Efficient Solid Oxide Fuel Cell Based upon Single-Phase Perovskites, Advanced Materials, 17, 14, (2005), 17341737 https://doi.org/10.1002/adma.200402007

[25]O. Madelung, U. Rössler, M. Schulz, NiO: lattice parameter, thermal expansion, in: LandoltBörnstein-Group III Condensed Matter 41D, NonTetrahedrally Bonded Binary Compounds II, SpringerMaterials, Berlin Heidelberg, 2000, https://doi.org/10.1007/10681735_510

[26]Gwenaël Corbel, Samih Mestiri, Philippe Lacorre, Physicochemical compatibility of CGO fluorite, LSM and LSCF perovskite electrode materials with $\mathrm{La}_{2} \mathrm{Mo}_{2} \mathrm{O}_{9}$ fast oxide-ion conductor, Solid State Sciences, 7, 10, (2005), 1216-1224 https://doi.org/10.1016/j.solidstatesciences.2005.05. 007

[27]Jing Chen, Dongjin Wan, Xuzhuo Sun, Bo Li, Interpretation of an inductive loop in the impedance of the impregnated $\mathrm{La}_{0.6} \mathrm{Sr}_{0.4} \mathrm{Co}_{0.2} \mathrm{Fe}_{0.8} \mathrm{O}_{3-\delta}-\mathrm{Y}_{2} \mathrm{O}_{3}$ stabilized $\mathrm{ZrO}_{2}$ cathodes, Journal of Electroanalytical Chemistry, 818, (2018), 231-235 https://doi.org/10.1016/j.jelechem.2018.04.032 